\title{
運動時の呼気延長呼吸が呼吸循環応答と自律神経活動に与える影響
}

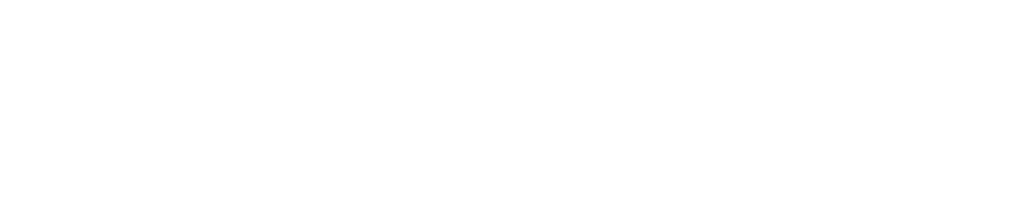

\section{EFFECTS OF THE BREATHING MODE CHARACTERIZED BY PROLONGED EXPIRATION ON RESPIRATORY AND CARDIOVASCULAR RESPONSES AND AUTONOMIC NERVOUS ACTIVITY DURING THE EXERCISE}

\author{
Takuya Matsumoto, atsuhiko Matsunaga, Miyako Hara, \\ MaSaKazU SaITOH, RYUSUKE YonezaWA, AKIRA ISHII, \\ TOSHIKI KUTSUnA, KAZUYA YamamoTO and TAKASHI MASUDA
}

\begin{abstract}
PURPOSE : The purpose of this study was to clarify the effects of prolonged expiration (PE) on respiratory and cardiovascular responses and autonomic nervous activity during the exercise.

METHODS : Twenty-five healthy men ( $22 \pm 1$ years) were classified according to the breathing mode during the exercise : 2 -second inspiration and 4-second expiration in $1: 2$ group, $3{ }^{-}$second inspiration and 3 -second expiration in $1: 1$ group and normal breathing in control group. The 6minute exercise was performed at anaerobic threshold (AT) and 60\%AT using a cycle ergometer as an exercise protocol. Respiratory rate (RR) and tidal volume (TV) were measured by the expired gas analysis. The power of $10 w^{-}$(LF) and high-frequency components (HF) was analyzed from a Holter electrocardiogram to assess the heart rate variability.

RESULTS : RR and LF/HF were significantly lower, TV and HF were significantly higher during the exercise of $60 \% \mathrm{AT}$ and AT in the $1: 1$ and $1: 2$ groups than in the control group $(\mathrm{P}<0.05$ or $P<0.01)$. The increase of HR was significantly lower and that of HF was significantly higher during the exercise at $60 \% \mathrm{AT}$ in the $1: 2$ group than in the $1: 1$ group $(\mathrm{P}<0.05)$.

CONCLUSION : PE activated the parasympathetic nervous activity and consequently restrained an excessive increase of $\mathrm{HR}$ during the exercise at $60 \% \mathrm{AT}$.

(Jpn. J. Phys. Fitness Sports Med. 2008, $57: 315 \sim 326$ )

key word : prolonged expiration, autonomic nervous activity, exercise, heart rate variability, cardiovascular response$$
\text { I .はじめに }
$$

運動によって変化する自律神経活動は, 呼吸循環 交感神経の均衡を変化させ呼吸循環応答を制御して (る ${ }^{4 \sim 6)}$. 一方で, 慢性心不全の患者, 特に重度 神経活動は減弱し交感神経活動が亢進しているた

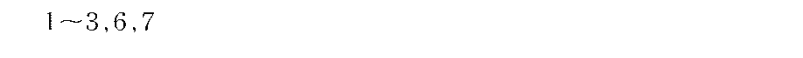
が過剩に六進して，血圧上昇や頻脈を生じ重篤な不 整脈を惹起する場合がある ${ }^{8,9)}$. 能患者に対して運動を処方する際には, 過乘な心血 管応答を引き起こさないように, 自律神経活動の変 化を考慮した適切な運動処方を行う必要がある。

一方, 心拍数が吸気時に早くなり呼気時に遅くな るという呼吸性洞性不整脈の発生には, 呼吸中枢に よる迷走神経節前ニューロンへの直接干渉と, 肺の 伸展受容体からの副交感神経への刺激か関与すると いわれている ${ }^{10 〜 12)}$.この自律神経活動を評価する
\end{abstract} 応答を規定する因子として知られ, 自律神経活動の 不均衡が生じると運動耐容能が低下すると報告され ている ${ }^{1 \sim 3)}$.一般に，健常者では運動強度に応じ た適切な酸素供給を維持するために, 交感神経と副 の心機能低下を示す患者では, 安静時から副交感 
方法として心拍変動解析が知られ, 谷のスペクトル 解析によって抽出される高周波成分 (HF) は呼吸性 洞性不整脈を反映するため，純粋な副交感神経活動 の指標として広く受(入れられている ${ }^{11,12)}$. 呼吸 による肺からの求心性インパルスの変化を検討した 研究では, 呼気時間を意識的に延長させた腹式呼吸 を安静時に行うと, 副交感神経活動が方進して血圧 や心拍数が低下し不整脈の出現が減少すること ${ }^{13}$, 14)，さらにこの呼吸を運動中に行うと換気効率が 改善することが報告されている15). しかしながら， 運動中に吸気時間と呼気時間の比率を変化させると 同時に呼吸数や分時換気量も変化するため, 呼吸樣 式の変化光のものが呼吸循環応答および自律神経活 動に与える影響については未だ一定の見解が得られ ていない .

弚こで, 本研究は呼吸数や分時換気量を制御した 上で, 嫌気性代謝閾值 (anaerobic threshold, AT) で ある中強度の運動と, ATの $60 \%$ である低強度の運 動を行い, 呼気延長を特徵とした呼吸樣式が運動中 の呼吸循環応答ならびに自律神経活動に与える影響 について検討した .

$$
\text { II. 方法 }
$$

\section{A. 対 象}

研究参加者は喫煙者を除外した若年健常男性25名 (年齢 $21.2 \pm 1.4$ 歳, 身長 $174.6 \pm 9.0 \mathrm{~cm}$, 体重 67.0 $\pm 8.9 \mathrm{~kg}$, body mass index $\left.22.1 \pm 1.7 \mathrm{~kg} / \mathrm{m}^{2}\right)$ とし た . 本研究のプロトコールは, 北里大学の倫理委員 会の承認を得た後, 研究参加者に対して研究の趣旨 を十分に説明し，書面にて同意を得て実施した . 測 定条件として, 研究参加者は測定前夜からアルコー ルの捸取や激しい運動を避け，また測定の 2 時間前 からは禁食とした . 測定は, 午後の決まった時間帯 に, 室温 $23 \sim 25^{\circ} \mathrm{C}$, 湿度 $40 \sim 60 \%$ に保たれた部屋で 実施された .

\section{B. 研究プロトコール}

自転車エルゴメータに乗って自然呼吸のまま15分 間の安静座位をとつた後, 呼吸樣式を制御しながら 自転車エルゴメータによる運動を 6 分間行い, 運動 後には自然呼吸による 5 分間の安静座位を設けた . 自転車エルゴメータによる運動強度は, AT 強度お よび AT の $60 \%$ 強度の 2 種類とし, AT の值は同年
齢の日本人男性の平均値を用いた ${ }^{16)}$. また，自転 車の回転速度は毎分50回転を保つように指示した。 呼吸樣式は, 運動中の呼吸数と分時換気量を一定に 保つために 1 呼吸周期を 6 秒間とし，吸気時間と呼 気時間の比が 2 秒対 4 秒の呼気延長の呼吸を行った 被験者 10 名を呼気延長群，吸気時間と呼気時間の比 が 3 秒対 3 秒の同比率である呼吸を行った被験者 10 名を同比率群，さらに対照として特別な指示をせず に自然呼吸のまま運動を行った被験者 5 名を自然呼 吸群として 3 群に分類した . 指定した呼吸樣式は， 運動中の 6 分間において実施され, 研究参加者は 1 秒に 1 回のリズムのピッチ音と呼気ガス分析器にリ アルタイムで表示される吸気時間・呼気時間に合わ せて呼吸するように指示された . 各群の研究参加者 は, $\mathrm{AT}$ 強度と $60 \% \mathrm{AT}$ 強度の 2 種類の運動を 24 時 間以上の間隔をあけて順不動に実施した .

\section{C. 測定項目}

Breath-by-breath 方式による呼気ガス分析装置 (AE300S, ミナト医科学, 大阪)を用いて, 呼吸数 (respiratory rate, RR), 吸気時間(inspiratory time, $\mathrm{Ti}$ )，呼気時間(expiratory time, $\mathrm{Te}$ ), 吸気時間と呼 気時間の比( $\mathrm{Te} / \mathrm{Ti}$ ), 1 回換気量(tidal volume, TV), 分時換気量 (respiratory minute volume, $\dot{V E}$ ), 酸素 搨取量 (uptake oxygen, $\dot{\mathrm{VO}}_{2}$ ) および二酸化炭素排出 量 (carbon-dioxide emission, $\dot{\mathrm{V} C O}{ }_{2}$ )を運動開始前の 安静座位の時点から測定した . 乥れ攵れの測定値か ら10秒毎の平均值を算出して呼吸応答の指標とし, さらに $\dot{\mathrm{VE}} / \mathrm{VCO}_{2}$ を算出して換気効率の指標とし た、自動血圧計(FB300，日本コーリン，愛知)を用 いて, 運動前は 5 分毎に, 運動中および運動後は 1 分毎に収縮期血圧 (systolic blood pressure, SBP) と 拡張期血圧 (diastolic blood pressure, DBP)を測定 し，心血管応答の指標とした ·また，ホルター心電 図(FM300，フクダ電子，東京)を測定開始時に装着 して心拍数 (heart rate, HR) を記録し, 光の R-R 間 隔から MemCalc(TARAWA/WIN, GMS 社, 東京) による最大エントロピー法で周波数解析を行った . 周波数解析は，0.04-0.15 Hz の低周波成分 $\left(\mathrm{low}^{-}\right.$ frequency component, LF)と $0.15-0.40 \mathrm{~Hz}$ の高周波 成分 (high-frequency component, HF)，光の比であ る $\mathrm{LF} / \mathrm{HF}$, さらにェントロピーを10秒毎の平均值 として算出し, HF を副交感神経活動の指標, LF/ 
HF を交感神経活動の優位性の指標, エントロピー を心拍変動の乱杂珄性の指標とした ${ }^{17 〜 20)}$. さらに， Borg Scale ${ }^{21)}$ を用いて運動前は 5 分毎, 運動開始時 から運動後の安静終了時までは 1 分毎に自覚的運動 強度 (raring of perceived exertion, RPE) を測定し た。

\section{D. 解析方法}

呼吸応答の各指標と RPE は, 運動中の 6 分間の 平均値を使用した . 心血管応答と自律神経活動の各 指標は, 運動前の安静15分間の最初と最後の 1 分間 を除いた13分間の平均值を安静時とし, 運動中と運 動後は 1 分毎に平均值を求め, 各指標を経時的な変 化で表示した . 次に , 6 分間の運動における各指標
の平均値から安静時に対する変化率 $(\%)$ を算出し た . 統計学的処理は, 運動中の 3 群間の比較には一 元配置分散分析，および Scheffe の多重比較を用い た。また, 群間(呼気延長群, 同比率群, 自然呼吸群) と時間(安静時, 運動中と運動後の 1 分毎の経時的 変化)の 2 要因,さらに群間(呼気延長群, 同比率群, 自然呼吸群) と強度 (60\% AT 強度, AT 強度)の 2 要因については关れ光れ二元配置分散分析, および Scheffe の多重比較を行った．なお，統計計算には SPSS $11.0 \mathrm{~J}$ for Windows を用いて, 統計学的有意 水準は $5 \%$ 末満とした。

$$
\text { III. 結果 }
$$

$60 \% \mathrm{AT}$ 強度と AT 強度の運動における呼吸応答

Table 1. Respiratory responses and RPE during the exercise of $60 \% \mathrm{AT}$ or AT.

\begin{tabular}{|c|c|c|c|c|c|c|c|}
\hline & control group & \multicolumn{2}{|l|}{ 1:1 group } & $1: 2$ group & \multicolumn{3}{|c|}{ F (ANOVA) P (ANOVA) } \\
\hline No. of subjects & 5 & 10 & & 10 & & & \\
\hline Age (years) & $21.3 \pm 1.2$ & $22.6 \pm 1.6$ & & $22.6 \pm 1.6$ & & 1.0 & NS \\
\hline Height (cm) & $176.7 \pm 9.5$ & $172.5 \pm 8.5$ & & $172.5 \pm 8.5$ & & 0.2 & NS \\
\hline Weight (kg) & $66.2 \pm 7.7$ & $67.7 \pm 10.1$ & & $67.7 \pm 10.1$ & & 0.1 & NS \\
\hline BMI & $21.2 \pm 0.6$ & $22.6 \pm 1.5$ & & $22.6 \pm 1.5$ & & 0.9 & NS \\
\hline \multicolumn{8}{|c|}{ exercise of $60 \% \mathrm{AT}$} \\
\hline $\mathrm{Ti}(\mathrm{sec})$ & $1.24 \pm 0.04$ & $2.90 \pm 0.03$ & ** & $2.06 \pm 0.04$ & $* *$,\#\# & 372.8 & $P<0.01$ \\
\hline Te (sec) & $1.70 \pm 0.04$ & $3.06 \pm 0.03$ & $* *$ & $3.94 \pm 0.04$ & **,\#\# & 407.5 & $P<0.01$ \\
\hline $\mathrm{Te} / \mathrm{Ti}$ & $1.37 \pm 0.07$ & $1.07 \pm 0.02$ & $* *$ & $1.96 \pm 0.04$ & $* *$,\#\# & 216.6 & $P<0.01$ \\
\hline RR (breath/min) & $21.0 \pm 0.8$ & $10.3 \pm 0.1$ & $* *$ & $10.1 \pm 0.1$ & $* *$ & 491.0 & $P<0.01$ \\
\hline TV (I) & $1.01 \pm 0.08$ & $2.02 \pm 0.14$ & $* *$ & $2.05 \pm 0.17$ & $* *$ & 6.2 & $P<0.01$ \\
\hline$\dot{V} E(1 / \min )$ & $20.7 \pm 1.1$ & $20.4 \pm 1.4$ & & $20.6 \pm 1.8$ & & 0.0 & NS \\
\hline$\dot{\mathrm{V}} \mathrm{O}_{2}(\mathrm{ml} / \mathrm{min} / \mathrm{kg})$ & $12.1 \pm 0.4$ & $11.7 \pm 0.2$ & & $11.9 \pm 0.2$ & & 0.7 & NS \\
\hline$\dot{\mathrm{VE}} / \dot{\mathrm{VCO}}_{2}$ & $35.8 \pm 0.6$ & $29.1 \pm 0.5$ & $* *$ & $29.3 \pm 0.6$ & $* *$ & 19.7 & $P<0.01$ \\
\hline RPE & $10.2 \pm 1.0$ & $7.3 \pm 0.5$ & $* *$ & $7.3 \pm 0.5$ & ** & 4.9 & $P<0.05$ \\
\hline \multicolumn{8}{|c|}{ exercise of AT } \\
\hline $\mathrm{Ti}(\mathrm{sec})$ & $1.22 \pm 0.10$ & $2.90 \pm 0.03$ & $* *$ & $2.07 \pm 0.05$ & **,\#\# & 239.0 & $P<0.01$ \\
\hline Te (sec) & $1.65 \pm 0.15$ & $3.10 \pm 0.03$ & $* *$ & $3.99 \pm 0.04$ & **,\#\# & 366.6 & $P<0.01$ \\
\hline $\mathrm{Te} / \mathrm{Ti}$ & $1.36 \pm 0.10$ & $1.08 \pm 0.02$ & $* *$ & $1.96 \pm 0.06$ & $* *$,\#\# & 97.0 & $\mathrm{P}<0.01$ \\
\hline RR (breath/min) & $21.7 \pm 1.4$ & $10.1 \pm 0.1$ & $* *$ & $10.0 \pm 0.1$ & $* *$ & 298.4 & $P<0.01$ \\
\hline TV (I) & $1.26 \pm 0.13$ & $2.37 \pm 0.14$ & $* *$ & $2.38 \pm 0.13$ & $* *$ & 9.4 & $P<0.01$ \\
\hline$\dot{V} E(V / m i n)$ & $26.5 \pm 2.6$ & $23.7 \pm 1.4$ & & $23.6 \pm 1.3$ & & 0.6 & NS \\
\hline $\mathrm{VO}_{2}(\mathrm{ml} / \mathrm{min} / \mathrm{kg})$ & $17.5 \pm 0.4$ & $15.7 \pm 0.2$ & & $15.8 \pm 0.3$ & & 1.3 & NS \\
\hline$\dot{\mathrm{VE}} / \mathrm{VCO}_{2}$ & $34.1 \pm 0.6$ & $27.2 \pm 0.3$ & ** & $27.6 \pm 0.2$ & $* *$ & 77.1 & $P<0.01$ \\
\hline RPE & $10.7 \pm 0.9$ & $7.8 \pm 0.7$ & $* *$ & $7.8 \pm 0.6$ & $* *$ & 2.8 & $P<0.05$ \\
\hline
\end{tabular}

Data are mean \pm SEM, $1: 2$ group ; controlled respiration of 2 -second inspiration and 4-second expiration, $1: 1$ group ; controlled respiration of 3-second inspiration and 3-second expiration, control group; normal breathing without a controlled respiration, ${ }^{* *} \mathrm{P}<0.01 \mathrm{vs}$. control group, ${ }^{\# \#} \mathrm{P}<0.01 \mathrm{vs} .1$ : 1 group, not significant, NS ; anaerobic threshold, AT ; body mass index, BMI ; inspiratory time, Ti ; expiratory time, $\mathrm{Te}$; respiratory rate, $\mathrm{RR}$; tidal volume, $\mathrm{TV}$; respiratory minute volume, $\dot{\mathrm{VE}}$; oxygen uptake, $\dot{\mathrm{VO}}_{2}$; carbondioxide emission, $\dot{\mathrm{VCO}}_{2}$; rating of perceived exertion, $\mathrm{RPE}$. 
と RPE を表1に示す. $60 \% \mathrm{AT}$ および AT 強度の 運動において, 同比率群と呼気延長群の Ti は, 自 然呼吸群に比べて有意に高值を示し(いずれも $\mathrm{P}<$ $0.01)$ ，呼気延長群の Ti は同比率群に比べて有意 に低值を示した(いずれも $\mathrm{P}<0.01)$. いずれの運動 強度においても, 呼気延長群の $\mathrm{Te}$ と $\mathrm{Te}$ / Ti は自 然呼吸群や同比率群に比べて有意に高值を示し(い ずれも $\mathrm{P}<0.01)$, 同比率群の $\mathrm{Te}$ と $\mathrm{Te} / \mathrm{Ti}$ は自然 呼吸群に比べて Te は有意に高值を(いずれも $\mathrm{P}<$ $0.01) ， \mathrm{Te} / \mathrm{Ti}$ は有意に低值を示した(いずれも $\mathrm{P}<$ $0.01)$. いずれの運動強度においても, 同比率群と 呼気延長群の $\mathrm{RR}, \dot{\mathrm{VE}} / \dot{\mathrm{V}} \mathrm{CO}_{2}$ と RPE は両群間で有 意差を認めなかったが, 自然呼吸群と比べて有意に 低值を示した(いずれも $\mathrm{P}<0.01)$. いずれの運動強
度においても, 同比率群と呼気延長群の TV は両 群間で有意差を認めなかったが, 自然呼吸群と比べ て有意に高值を示した(いずれも $\mathrm{P}<0.01)$.

$60 \%$ AT 強度と AT 強度の運動における血圧の経 時的変化を図 $1 \mathrm{a}$ と図 $1 \mathrm{~b}$ に, 弚れ光れの安静時に 対する運動中の血圧の変化率を図 $1 \mathrm{c}$ に示す.いず れの運動強度においても, SBP は 3 群ともに安静 時に比べて運動中に有意に増加したが(いずれも $\mathrm{P}$ $<0.01$ ) (図 $1 \mathrm{a}$, 図 $1 \mathrm{~b}$ ), 安静時に対する運動中の $\mathrm{SBP}$ の上昇の程度は 3 群間で有意差を認めなかっ た(図 $1 \mathrm{c})$.いずれの運動強度においても，DBP は 3 群ともに安静時に比べて運動中に有意に低下した が(いずれも $\mathrm{P}<0.05$ )(図 $1 \mathrm{a}$ ，図 $1 \mathrm{~b}$ )，安静時に対 する運動中の DBP の低下の程度には 3 群間で有意
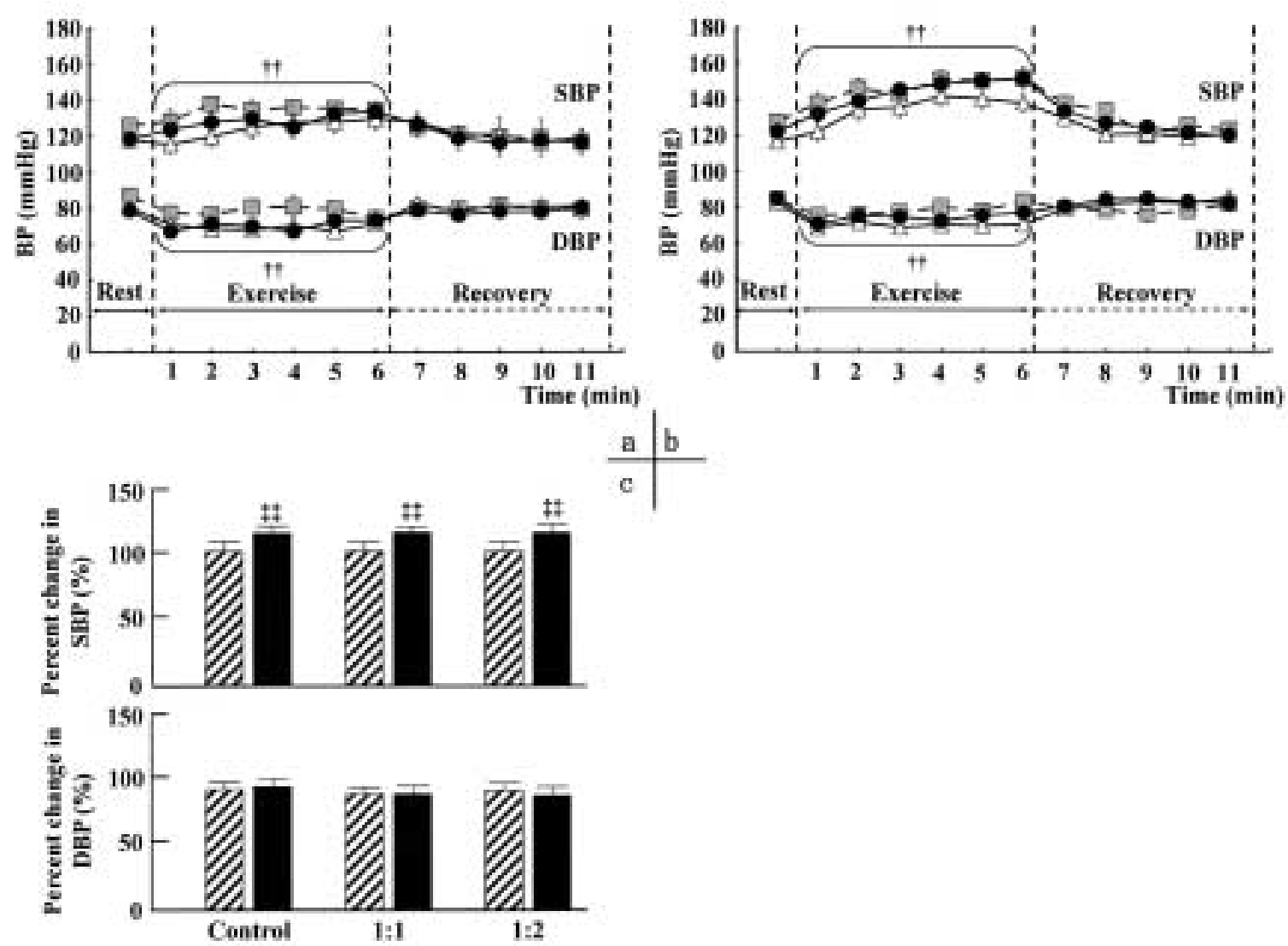

Figure 1. Changes of BP at the exercise of $60 \% \mathrm{AT}(\mathrm{a})$ or AT (b) and percent changes in BP (c). Data are mean \pm SEM, : 1:2 group ; controlled respiration of 2-second inspiration and 4-second expiration, $\triangle: 1: 1$ group ; controlled respiration of 3 -second inspiration and $3-$ second expiration, $\square$ : control group; normal breathing without a controlled respiration, $\mathbb{Z}$ : exercise of $60 \% \mathrm{AT}, \mathbf{\square}$ : exercise of $\mathrm{AT}, ~ \dagger \dagger \mathrm{P}<0.01$ vs. rest, $+\ddagger \mathrm{P}<0.01$ vs. exercise of $60 \% \mathrm{AT}$, anaerobic threshold, $\mathrm{AT}$; blood pressure, BP; systolic blood pressure, SBP; diastolic blood pressure, DBP. The results of the two-way ANOVA for repeated measures were as follows; time effects in SBP and DBP at the exercise of $60 \% \mathrm{AT}$ ( $\mathrm{SBP}: \mathrm{F}=8.6, \mathrm{DBP}: \mathrm{F}=4.4, \mathrm{P}<0.01$, respectively) and $\mathrm{AT}$ ( $\mathrm{SBP}: \mathrm{F}=7.9, \mathrm{DBP}: \mathrm{F}$ $=8.0, \mathrm{P}<0.01$, respectively), and exercise intensity effect in the increase of $\mathrm{SBP}$ during the exercise of $60 \% \mathrm{AT}$ and $\mathrm{AT}(\mathrm{F}=7.4, \mathrm{P}<0.01)$. 
差を認めなかった(図 $1 \mathrm{c}$ ). 一方，60\%AT 強度と AT 強度の運動における血圧の変化を比較すると， 3 群ともに $60 \% \mathrm{AT}$ 強度に比べて AT 強度で有意 に高值を示したが(いずれも $\mathrm{P}<0.01) ， \mathrm{DBP}$ は強度 間に有意差を認めなかった(図 1 c) .

$60 \% \mathrm{AT}$ 強度と AT 強度の運動における HR の経 時的変化を図 $2 \mathrm{a}$ と図 $2 \mathrm{~b}$ に, 弚れ光れの安静時に 対する運動中の HR の変化率を図 $2 \mathrm{c}$ に示す.いず れの運動強度においても, HR は 3 群ともに安静時 に比べて運動中に有意に増加した(いずれも $\mathrm{P}<$ 0.01 ) (図 $2 \mathrm{a}$, 図 $2 \mathrm{~b}$ ). 安静時に対する運動中の HR の上昇の程度は, $60 \% \mathrm{AT}$ 強度の運動では呼気 延長群は同比率群に比べて有意に低值を示したが $(\mathrm{P}<0.05), \mathrm{AT}$ 強度では 3 群間で有意差を認めな かった(図 $2 \mathrm{c}$ ). 一方, 60\% AT 強度と AT 強度の 運動における HR の変化を比較すると, 3 群ともに
$60 \% \mathrm{AT}$ 強度に比べて AT 強度で有意に高値を示し た(いずれも $\mathrm{P}<0.01$ ) (図 $2 \mathrm{c}$ ).

$60 \% \mathrm{AT}$ 強度と AT 強度の運動における HF の経 時的変化を図 $3 \mathrm{a}$ と図 $3 \mathrm{~b}$ に, 光れぞれの安静時に 対する運動中の HF の変化率を図 $3 \mathrm{c}$ に示す . $60 \%$ AT 強度では, 自然呼吸群の HF は安静時に比べて 運動中に有意に低下したが $(\mathrm{P}<0.01)$, 同比率群と 呼気延長群の HF は運動 3 分目から 6 分目に有意に 増加した(いずれも $\mathrm{P}<0.05$ ) (図 $3 \mathrm{a}$ ). AT 強度で は, 自然呼吸群の HF は安静時に比べて運動中に有 意に低下したが $(\mathrm{P}<0.05)$, 同比率群と呼気延長群 の HF は運動中に有意な変化を示さなかった(図 3 b) . 安静時に対する運動中の HF の上昇の程度は, $60 \% \mathrm{AT}$ 強度では呼気延長群の HF は自然呼吸群と 同比率群に比べて有意に高值を示し $(\mathrm{P}<0.01, \mathrm{P}<$ $0.05)$, 同比率群の HF は自然呼吸群に比べて有意
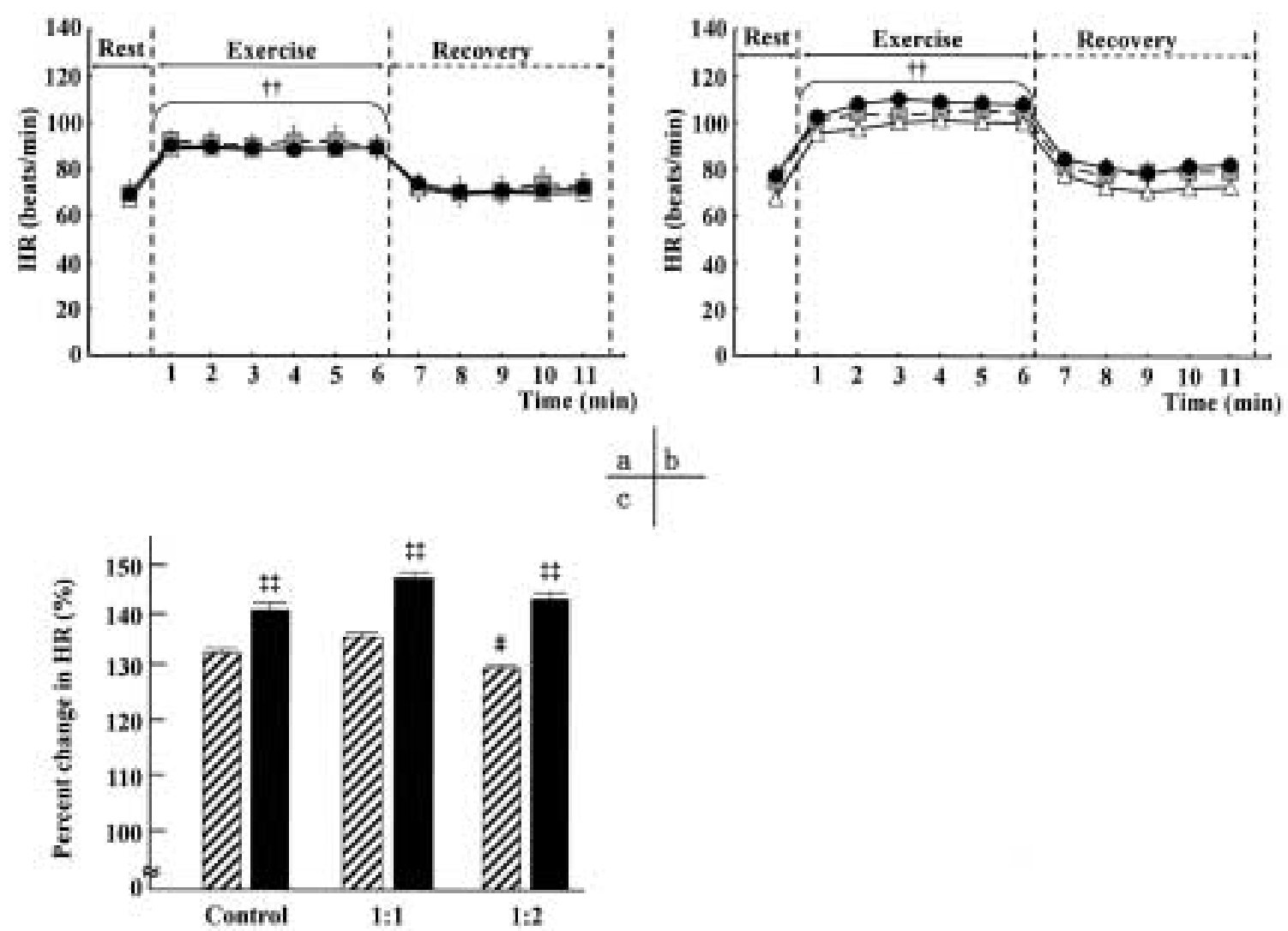

Figure 2. Changes of HR at the exercise of $60 \% \mathrm{AT}$ (a) or AT (b) and percent changes in HR (c). Data are mean \pm SEM, : $1: 2$ group ; controlled respiration of 2 -second inspiration and 4-second expiration, $\triangle: 1: 1$ group; controlled respiration of 3 -second inspiration and 3 -second expiration, $\square$ : control group ; normal breathing without a controlled respiration, $\mathbb{Z}$ : exercise of $60 \% \mathrm{AT}, \mathbf{\square}$ : exercise of AT, \# P<0.05 vs. $1: 1$ group, $\dagger \dagger P<0.01$ vs. rest, $\pm+P<0.01$ vs. exercise of $60 \% \mathrm{AT}$, anaerobic threshold, AT ; heart rate, HR. The results of the two-way ANOVA for repeated measures were as follows; time effect in $\mathrm{HR}$ at the exercise of $60 \% \mathrm{AT}(\mathrm{F}=162.5, \mathrm{P}<0.01)$ and $\mathrm{AT}(\mathrm{F}=183.2$, $\mathrm{P}<0.01)$, and exercise intensity effect in the increase of HR during the exercise of $60 \% \mathrm{AT}$ and $\mathrm{AT}$ $(\mathrm{F}=12.6, \mathrm{P}<0.01)$. 

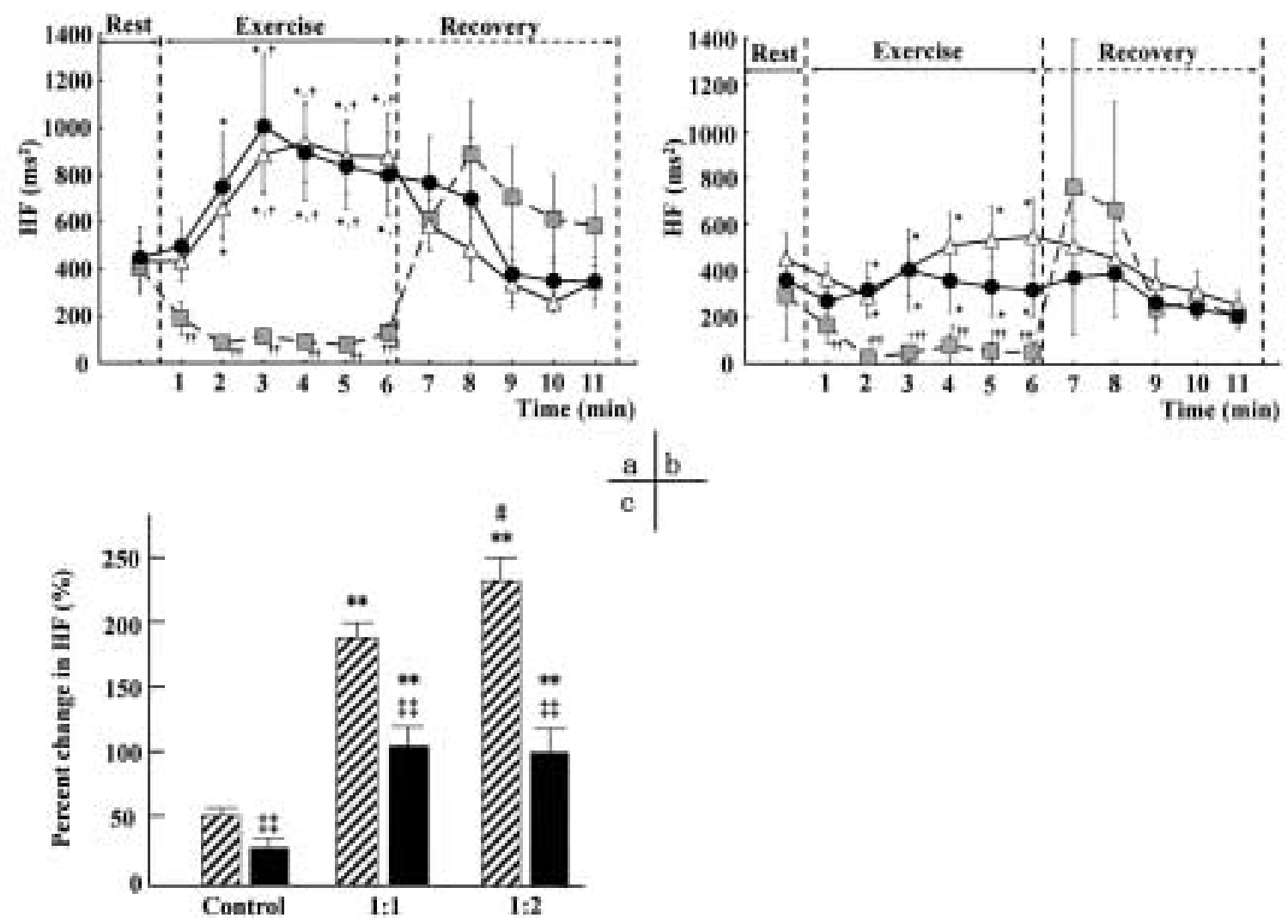

Figure 3. Changes of HF at the exercise of $60 \% \mathrm{AT}$ (a) or AT (b) and percent changes in HF (c). Data are mean \pm SEM, : $1: 2$ group ; controlled respiration of 2-second inspiration and 4-second expiration, $\triangle: 1: 1$ group; controlled respiration of 3 -second inspiration and 3 -second expiration, $\square$ :control group ; normal breathing without a controlled respiration, $\mathbb{Z}$ : exercise of $60 \%$ AT, $\mathbf{\square}$ : exercise of $\mathrm{AT},{ }^{*} \mathrm{P}<0.05,{ }^{* *} \mathrm{P}<0.01$ vs. control group, \# $\mathrm{P}<0.05$ vs. $1: 1$ group, $\dagger \mathrm{P}<0.05, \dagger \dagger \mathrm{P}$ $<0.01$ vs. rest, $¥+\mathrm{P}<0.01$ vs. exercise of $60 \% \mathrm{AT}$, anaerobic threshold, AT; high-frequency components in heart rate variability, HF. The results of the two-way ANOVA for repeated measures were as follows; group $\times$ time interactions in $\mathrm{HF}$ at the exercise of $60 \% \mathrm{AT}(\mathrm{F}=2.4, \mathrm{P}<0.01)$ and $\mathrm{AT}$ $(\mathrm{F}=3.3, \mathrm{P}<0.01)$, and group effect $(\mathrm{F}=6.5, \mathrm{P}<0.01)$ and exercise intensity effect $(\mathrm{F}=4.2, \mathrm{P}<$ $0.05)$ in the increase of HF during the exercise of $60 \% \mathrm{AT}$ and $\mathrm{AT}$.

に高値を示した $(\mathrm{P}<0.01$ ) (図 $3 \mathrm{c}$ ). AT 強度では同 比率群および呼気延長群の HF は自然呼吸群に比べ て有意に高値を示したが(いずれも $\mathrm{P}<0.01)$ ，同比 率群と呼気延長群の間には有意差を認めなかった (図 $3 \mathrm{c}$ ). 一方, 60\% AT 強度と AT 強度の運動に おける HF の変化を比較すると， 3 群ともに $60 \%$ $\mathrm{AT}$ 強度に比べて AT 強度で有意に低值を示した (いずれも $\mathrm{P}<0.01$ ) (図 $3 \mathrm{c}$ ).

$60 \% \mathrm{AT}$ 強度と AT 強度の運動における LF/HF の経時的変化を図 $4 \mathrm{a}$ と図 $4 \mathrm{~b}$ に, 乥れ光れの安静 時に対する運動中の $\mathrm{LF} / \mathrm{HF}$ の変化率を図 $4 \mathrm{c}$ に示 す.いずれの運動強度においても, 自然呼吸群の $\mathrm{LF} / \mathrm{HF}$ は安静時に比べて運動 1 分目に有意に増加 したが $(\mathrm{P}<0.01)$, 同比率群と呼気延長群の $\mathrm{LF} / \mathrm{HF}$ は運動中に有意に低下した(いずれも $\mathrm{P}<0.05$ ) (図
$4 \mathrm{a}$, 図 $4 \mathrm{~b})$ ．安静時に対する運動中の LF/HF の 上昇の程度は，いずれの運動強度においても，自然 呼吸群に比べて同比率群と呼気延長群で有意に低値 を示した(いずれも $\mathrm{P}<0.01$ )(図 4c).一方，60\% $\mathrm{AT}$ 強度と AT 強度の運動における $\mathrm{LF} / \mathrm{HF}$ の変化 を比較すると, $\mathrm{LF} / \mathrm{HF}$ は 3 群ともに $60 \% \mathrm{AT}$ 強度 と AT 強度の間で有意差を認めなかった．

$60 \% \mathrm{AT}$ 強度と AT 強度の運動におけるエントロ ピーの経時的変化を図 $5 \mathrm{a}$ と図 $5 \mathrm{~b} に$, 光れ光れの 安静時に対する運動中のエントロピーの変化率を図 $5 \mathrm{c}$ に示す. $60 \% \mathrm{AT}$ 強度では, 自然呼吸群のエン トロピーは安静時と比べて運動中に有意に低下した が $(\mathrm{P}<0.05)$, 同比率群と呼気延長群のエントロ ピーは運動中に有意な変化を示さなかった(図 5 a). $\mathrm{AT}$ 強度では, 3 群のエントロピーは安静時と比べ 

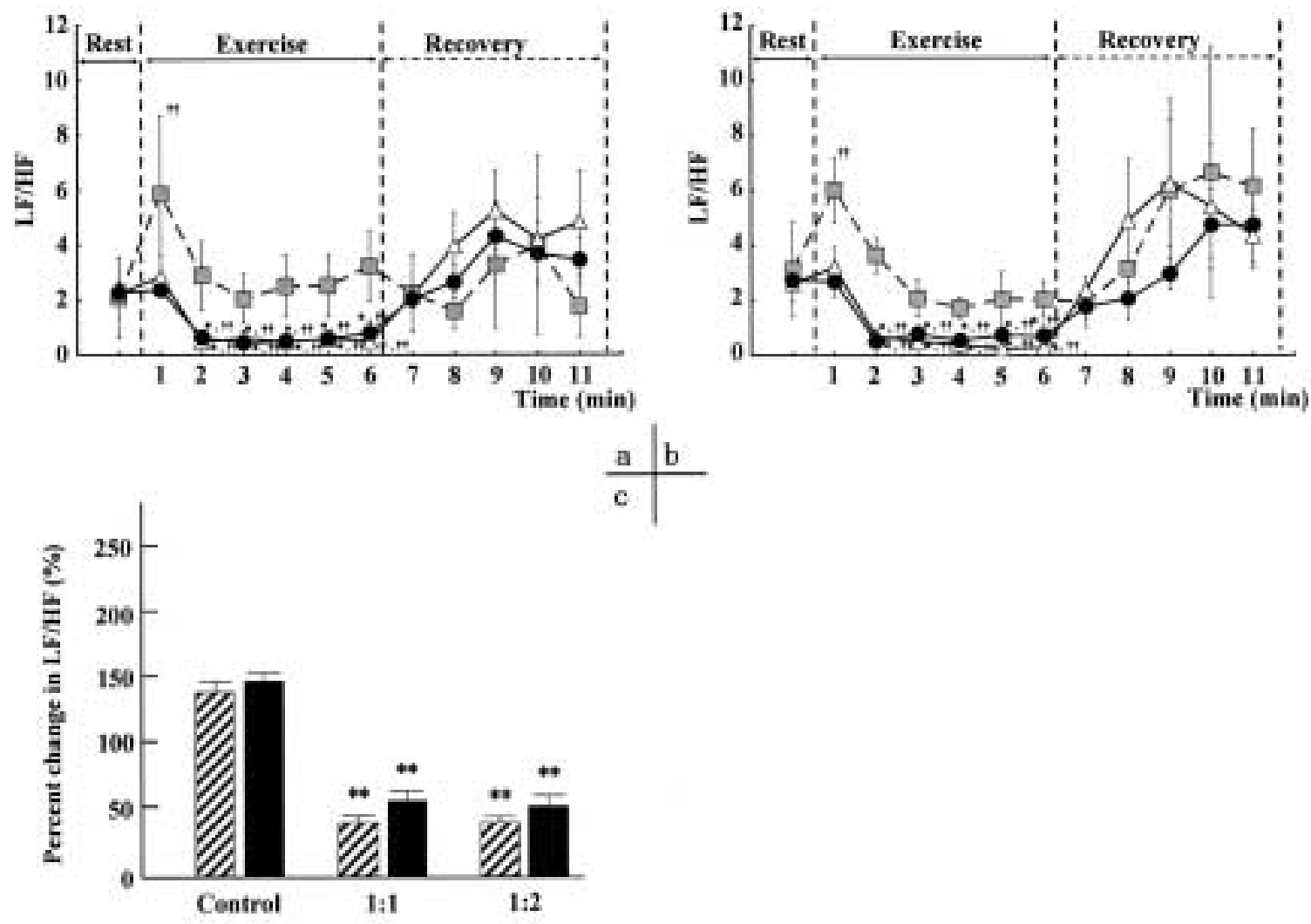

Figure 4. Changes of $\mathrm{LF} / \mathrm{HF}$ at the exercise of $60 \% \mathrm{AT}$ (a) or AT (b) and percent changes in LF/ $\mathrm{HF}(\mathrm{c})$.

Data are mean \pm SEM, $: 1: 2$ group ; controlled respiration of 2 -second inspiration and 4-second expiration, $\triangle: 1: 1$ group ; controlled respiration of 3 -second inspiration and 3 -second expiration, $\square$ : control group ; normal breathing without a controlled respiration, $\mathbb{Z}$ : exercise of $60 \% \mathrm{AT}, \mathbf{\square}$ : exercise of $\mathrm{AT},{ }^{*} \mathrm{P}<0.05,{ }^{* *} \mathrm{P}<0.01 \mathrm{vs}$. control group, $\dagger \mathrm{P}<0.05, \dagger \dagger \mathrm{P}<0.01 \mathrm{vs}$. rest, anaerobic threshold, AT; low-frequency components in heart rate variability, LF ; high-frequency components in heart rate variability, $\mathrm{HF}$; the ratio of LF to $\mathrm{HF}$ in heart rate variability, LF/ HF. The results of the two-way ANOVA for repeated measures were as follows; group $\times$ time interactions in $\mathrm{LF} / \mathrm{HF}$ at the exercise of $60 \% \mathrm{AT}(\mathrm{F}=1.9, \mathrm{P}<0.05)$ and $\mathrm{AT}(\mathrm{F}=2.0, \mathrm{P}<0.01)$, and group effect in the increase of $\mathrm{LF} / \mathrm{HF}$ during the exercise of $60 \% \mathrm{AT}$ and $\mathrm{AT}(\mathrm{F}=6.5, \mathrm{P}<0.01)$.

て運動中に有意に低下した(いずれも $\mathrm{P}<0.01$ ) (図 5 b) . 安静時に対する運動中のエントロピーの低 下の程度は , いずれの運動強度においても3 群間で 有意差を認めなかった (図 $5 \mathrm{c}$ ) 。一方，60\% AT 強 度と AT 強度の運動におけるエントロピーの変化 を比較すると，3 群ともに $60 \% \mathrm{AT}$ 強度と比べて AT 強度で有意に低值を示した(いずれも $\mathrm{P}<0.05)$ (図 $5 \mathrm{c}$ ).

$$
\text { N. 考察 }
$$

呼吸樣式と自律神経活動の関係を検討した従来の 報告では, 副交感神経活動を反映する HF は深呼吸 あるいは腹式呼吸で増大し，この賦活化した副交感 神経活動によって BP や HR が低下することが知ら
れている ${ }^{11,13,14,22 \sim 27)}$. 逆に, 頻呼吸や TV を減 少させた呼吸あるいは呼吸を止めると, 副交感神経 活動は減弱し BP や HR が増加すると報告されてい $3^{11,26 \sim 28)}$. しかし, 呼気時間を変化させて呼吸 を行うと，吸気時間と呼気時間の比率ばかりでなく 同時に RR, TV, $\dot{V} E$ も変化するため, 吸気時間と 呼気時間の比率だけを変化させて呼吸循環応答およ び自律神経活動を検討した報告は極めて少ない，光 こで, 本研究では呼吸周期を 6 秒に設定し，運動中 の RR を一定にした上で吸気時間と呼気時間の比率 を变更した．关の結果， $60 \% \mathrm{AT}$ 強度および AT 強 度のいずれの運動においても, 自然呼吸群の RR は 約20回/分であったのに対し呼気延長群と同比率群 の RR は約10回/分と一定に保たれていた.さらに， 

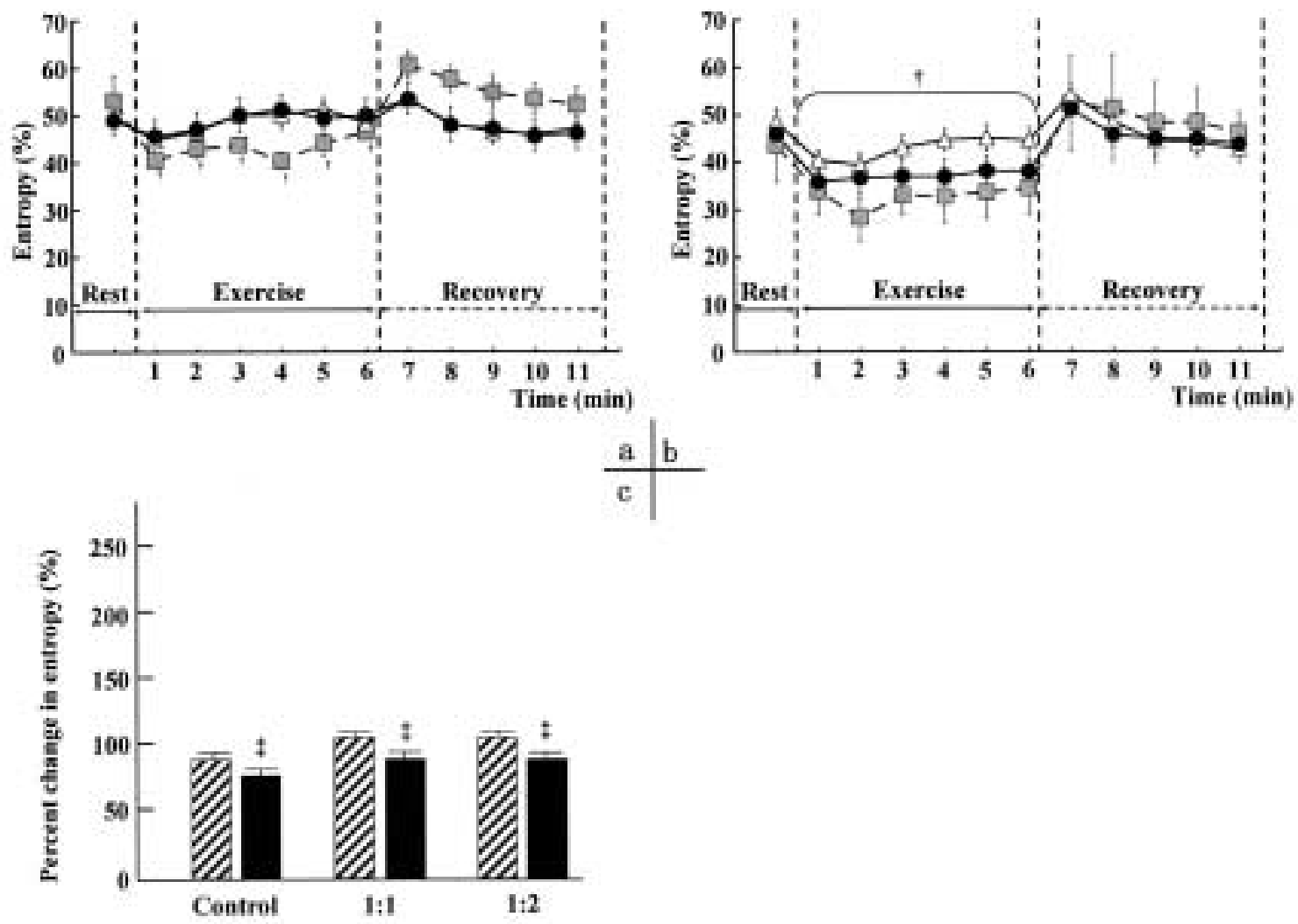

Figure 5. Changes of entropy at the exercise of $60 \% \mathrm{AT}(\mathrm{a})$ or AT (b) and percent changes in entropy $(c)$.

Data are mean \pm SEM, : $1: 2$ group ; controlled respiration of 2-second inspiration and 4-second expiration, $\triangle: 1: 1$ group ; controlled respiration of 3 -second inspiration and 3 -second expiration, $\square$ : control group ; normal breathing without a controlled respiration, $\mathbb{Z}$ : exercise of $60 \% \mathrm{AT}, \mathbf{\square}$ : exercise of AT, $\dagger \mathrm{P}<0.05$ vs. rest, $\ddagger \mathrm{P}<0.05$ vs. exercise of $60 \% \mathrm{AT}$, anaerobic threshold, $\mathrm{AT}$; complexity of heart rate variability, Entropy. The results of the two-way ANOVA for repeated measures were as follows; group $X$ time interaction in Entropy at the exercise of $60 \% \mathrm{AT}(\mathrm{F}=1.7, \mathrm{P}$ $<0.05)$, and time effect in Entropy at the exercise of $\mathrm{AT}(\mathrm{F}=2.0, \mathrm{P}<0.01)$, and exercise intensity effect in the decrease of Entropy during the exercise of $60 \% \mathrm{AT}$ and $\mathrm{AT}(\mathrm{F}=4.8, \mathrm{P}<0.01)$.

呼気延長群と同比率群の運動中の $\dot{V} \mathrm{E}$ および TV にも有意差は認められなかったことから, 本研究で はRRや TVを一定に保った上で吸気時間と呼気時 間の比率を変化できたと考えられた。

一方, 本研究では心疾患患者に対し運動療法開始 時に処方される低強度の $60 \% \mathrm{AT}$ と, 一般的な運 動療法として処方される中等度強度の AT を運動 強度として設定した。弚の結果， $60 \% \mathrm{AT}$ 強度およ び AT 強度の呼吸応答は, いずれの運動強度にお いても呼気延長群と同比率群は自然呼吸群と比較し て RR と $\dot{\mathrm{VE}} / \mathrm{VCO}_{2}, \mathrm{RPE}$ が有意に低値を，TVは 有意に高値を示したことから, 呼気延長群と同比率 群の呼吸樣式は換気効率が向上した深呼吸であり， 自覚的に楽な運動であることが示された .

$60 \% \mathrm{AT}$ 強度の運動における循環応答と自律神経
活動の検討では, SBP は 3 群ともに安静時に比べ て運動中に有意に増加したが, 兴の運動中の SBP の増加率には 3 群間で有意差を認めなかった . 一 方, HR は 3 群ともに安静時に比べて運動中に有意 に増加し，光の運動中の HR の増加率を比較する と, 呼気延長群は同比率群に比へて有意に低値を示 した .この時の呼気延長群の HF は, 安静時に比べ て運動中に有意に増加し, 同比率群や自然呼吸群の HF に比べても有意に高値を示していた．また，自 然呼吸群の LF/HF は安静時に比べて運動中に有意 に増加したのに対して, 呼気延長群と同比率群の $\mathrm{LF} / \mathrm{HF}$ は安静時に比べて運動中に有意に低下して いた .さらに, エントロピーは自然呼吸群では安静 時と比べて運動中に有意に低下したのに対し, 呼気 延長群と同比率群では安静時と比へて運動中に有意 
な変化を示さなかった .一般に, 呼吸に伴う副交感 神経活動の変化は, 肺の伸展受容器からの入力に よって吸気時に遮断され呼気時に刺激されるため, その活動は呼気時に賦活化されることが知られてい $3^{11)}$. 本研究において, 自然呼吸群と比較して同 比率群や呼気延長群で副交感神経活動がより賦活 化した理由として, RR の減少 11,26,27)や TV の増 加 $^{11,26,27)}$ による呼気時の副交感神経活動の亢進が 考えられた .さらに, 同比率群と比べて呼気時間の より長い呼気延長群において, 副交感神経活動の亢 進がより顕著に表れたと思われた .これらの結果か ら，60\%AT のような低強度の運動に呼気延長の呼 吸樣式を導入すると, 副交感神経活動か賦活化し相 対的に交感神経活動が減弱するため, 運動中に生じ る HR 上昇が抑制されることが示された。我々は， 既に若年健常男性を対象に, 呼気延長群と同比率群 に分類し， $65 \% \mathrm{AT}$ 強度で30分間の自転車エルゴ メータ負荷を行い, 呼気延長群は同比率群と比べて 運動中ならびに運動後の副交感神経活動を賦活化 し，運動中の HR と RPE の上昇を抑制すると報告 した ${ }^{29)}$. 本研究は, この予備研究と同樣の結果で あり, 呼気延長の呼吸樣式が副交感神経活動を賦活 化し運動中の HR を抑制するという事実を確認でき たと考えられた.しかし, 自然呼吸群と比較して呼 気延長群の副交感神経活動は賦活化したにもかかわ らず，HRに有意差を認めなかった . 運動時におけ る循環調節機序の一つである central command は， 中枢性に副交感神経活動を抑制することで運動初期 あるいは低強度の運動時の HR 上昇を調節すると報 告されている ${ }^{4)} .60 \% \mathrm{AT}$ 強度のような低強度の運 動でも, central command による上位中枢からの副 交感神経活動の抑制によっていずれの群においても HR が増加するように作用している.一方で, 呼気 延長群では主に心藏の副交感神経活動の賦活化によ る HR 上昇に対する抑制が加わるが, central command の作用による上位中枢からの副交感神経活動 抑制を上回るほどの副交感神経活動の賦活化は得ら れなかったため, 呼気延長群と自然呼吸群の HRに 有意差を認めなかったと考えられた . エントロピー に関しては, 交感神経を遮断するとエントロピーは 増大し，交感神経と副交感神経の双方を遮断すると 著しく低下することから，心拍変動の乱雑性を表す 指標とされている ${ }^{17 〜 20)}$. 健常者における運動とエ
ントロピーの関係を検討した報告では，平均21歳の 女性アスリートに自転車エルゴメータを用いて AT 程度の運動を30分間行ったところ，運動開始から交 感神経活動は六進し副交感神経活動か減弱して，工 ントロピーは速やかに低下することが示された . ま た，運動か終了すると交感神経活動の六進は徐々に 回復し副交感神経活動は賦活化するため，エントロ ピーは増加すると報告している ${ }^{17)}$. 本研究におい ては, 呼気延長の呼吸樣式では, $60 \% \mathrm{AT}$ 強度の運 動で副交感神経活動は賦活化し交感神経活動の六進 は抑制されたことから，エントロピーの低下は生じ なかったと思われた .

一方，AT 強度の運動における循環応答と自律神 経活動の検討では，SBP と HR は 3 群ともに安静 時に比べて運動中に有意に増加し，光の増加の程度 は 3 群間に有意差を認めなかった .また，自然呼吸 群の HF は安静時に比べて運動中に低下したのに対 し，呼気延長群と同比率群の HF は運動中に有意な 変化を示さず, この時の $\mathrm{LF} / \mathrm{HF}$ は, 自然呼吸群に 比べて呼気延長群と同比率群では運動中に有意に低 值を示した .さらに，エントロピーは，3 群ともに 安静時と比べて運動中に有意に低下したが, 安静時 に対する運動中のエントロピーの低下の程度には 3 群間に有意差を認めなかった .これらのことから， AT 強度の運動では, 呼気延長の呼吸樣式は運動中 の交感神経活動を抑制するにも拘らず，低強度の運 動に比べて副交感神経活動の賦活化が弱まるため HR の上昇を抑制する効果が減弱したと考えられ た。一方，運動強度が強くなり AT 強度に達する と，交感神経活動はより方進し副交感神経活動は著 しく減弱するため，呼気樣式に関係なくエントロ ピーは低下したと思われた .

一般に, 漸増負荷運動における自律神経活動の変 化として, 副交感神経活動は運動負荷の開始ととも に速やかに抑制されるが, 交感神経活動は AT 強 度に達するまでは変化を示さない．AT 強度以上と なると副交感神経活動は著しく減弱し，交感神経活 動は相対的に増加すると云われている ${ }^{4,7,30 〜 32)}$. しかし, 本研究で示したように中等度の強度までの 運動では，適切な呼気延長の呼吸樣式を実施するこ とによって, 副交感神経活動か賦活化し HR 上昇が 抑制されて，換気効率が向上し自覚的に楽な運動 になると思われた．以上から，AT 強度以下の運動 
でも過剩な心循環応答を示す高齢者や低心機能患 者 $^{8,9)}$ を対象とした場合は, 呼気延長の呼吸樣式を 導入することによって自然呼吸の運動より安全な運 動が行えると考えられた .

(受理日 平成20年 2 月 25 日)

$$
\mathrm{V} \text {. 文献 }
$$

1) Coats A. J., Adamopoulos S., Radaelli A., McCance A., Meyer T. E., Bernardi L., Solda P. L., Davey P., Ormerod O., Forfar C. Controlled trial of physical training in chronic heart failure : exercise performance, hemodynamics, ventilation, and autonomic function. Circulation, (1992), 85, 2119-2131.

2) 早野順一郎, 循環器疾患と自律神経機能, 第 2 版, 冠動脈疾患, 医学書院, 東京, (2001)，139-162.

3) 麻野井英次, 循環器疾患と自律神経機能, 第 2 版, 心不全における循環調節異常, 医学書院, 東京, (2001)，163-195.

4) 麻野井英次, 循環器疾患と自律神経機能, 第 2 版, 自律神経系による循環調節，医学書院，東京，(2001)， 19-43.

5) Pierpont G. L., Voth E. J. Assessing autonomic function by analysis of rate recovery from exercise in healthy subjects. Am. J. Cardiol., (2004), 94, 64-68.

6) Floras J. S. Clinical aspects of sympathetic activation and parasympathetic withdrawal in heart failure. J. Am. Coll. Cardiol., (1993), 22, 72A-84A.

7) 安達 仁, 心肺運動負荷テストと運動療法, 初版, 運動療法と運動処方, 南江堂, 東京, (2004), 240276 .

8) 松永篤彦, 中村 彩, 急性期心筋梗塞患者の機械卜 レーニングに対する適応の検討 . 北里医学 , (2000), $30,439-449$.

9) Matsunaga A., Masuda T., Ogura N. M., Saitoh M., Kasahara Y., Iwamura T., Yamaoka TM., Sato K., Izumi T. Adaptation to low-intensity exercise on a cycle ergometer by patients with acute myocardial infarction undergoing phase I cardiac rehabilitation. Circulation J., (2004), 68, 938-945.

10) Task Force of the European Society of Cardiology the North American Society of Pacing Electrophysiology. Heart rate variability : standards of measurement, physiological interpretation, and clinical use. Circulation, (1996), 93, 1043-1065.

11) 早野順一郎, 循環器疾患と自律神経機能, 第 2 版, 心拍変動による自律神経機能解析, 医学書院, 東京, (2001) , 71-109.

12) Yasuma F., Hayano J. Respiratory sinus arrhythmia : why does the heartbeat synchronize with respiratory rhythm? Chest, (2004), 125, 683-690.

13) 片岡秋子, 渋谷菜穂子, 腹式呼吸における呼気吸気 時間の変化が及ぼす自律神経への影響, 日本看護科 学会誌, (2002), 4, 14-18.
14) 福本真理, 坪井かほる, 大海理香, 稲葉純子, 安達 仁, 谷口興一, 腹式呼吸は心笳梗塞急性期の副交感 神経を賦活させる 心蔵リハビリテーション,(1998), $3,97-100$.

15) 横山茂樹, 千住秀明, 菅原正志, 田井村明博, 運動 中において腹式呼吸による呼吸コントロールが呼吸 循環動態に及ぼす影響, 長崎大学医学部保健学科紀 要, (2002), 15, 63-68.

16) 日本循環器学会・運動に関する診療基準委員会, 日 本人の運動時呼吸循環指標の標準値, Jpn. Circ. J., (1992), 56, 1514-1523.

17) Oida E., Moritani T., Yamori Y. Tone-entropy analysis on cardiac recovery after dynamic exercise. J. Appl. Phisiol., (1997), 82, 1794-1801.

18) Oida E., Kannagi T., Moritani T., Yamori Y. Aging alteration of cardiac vagosympathetic balance assessed through the tone-entropy analysis. J. Gerontol. A Biol. Sci. Med. Sci., (1999), 54A, M219-24.

19 ) 笈田映一, 池田克巳, 家森幸男, 心臓自律神経活性 の心拍変動解析による絶対評価と, 弚の臨床応用の 試み, セラピューティック・リサーチ , (2001) , 22， 2691-2693.

20) Amano M., Oida E., Moritani T. A comparative scale of autonomic function with age through the toneentropy analysis on heart period variation. Eur. J. Appl. Physiol., (2006), 98, 276-283.

21) アメリカスポーツ医学会編 (日本体力医学会体力科学 編集委員会監約), 体力測定および炎の解釈, 運動処 方の指針，原著第 6版,南江堂，東京，(2001)，54-88.

22) Bernardi L., Spadacini G., Bellwon J., Hajric R., Ros. kamm H., Frey A. W. Effect of breathing rate oxygen saturatio and exercise performance in chronic heart failure. Lanset, (1998), 351, 1308-1311.

23) Goso Y., Asanoi H., Ishise H., Kameyama T., Hirai T., Nozawa T., Takashima S., Umeno K., Inoue H. Re. spiratory modulation of muscle sympathetic nerve activity in patients with chronic heart failure. Circulation, (2001), 104, 418-423.

24) Bernardi L., Porta C., Spicuzza L., Bellwon J., Spadacini G., Frey A. W., Yeung L. Y. C., Sanderson J. E., Pedretti R., Tramarin R. Slow breathing increases arterial baroreflex sensitivity in patients with chronic heart failure. Circulation, (2002), 105, 143-145.

$25)$ Joseph C. N., Porta C., Casucci G., Casiraghi N., Maffeis M., Rossi M., Bernardi L. Slow breathing im. proves arterial baroreflex sensitivity and decreases blood pressure in essential hypertension. Hyperten. sion, (2005), 46, 714-718.

26) 中尾睦宏, 熊野宏昭, 久保木富房, 末松弘行, 安士 光男, 高島香代子, 呼吸回数が心拍変動に与える影 響について，心身医，(1995)，35，455-462.

27 ) 奥田忠行, 桜川信男, 梅野克身, 柴原直利, 心拍変 動と呼吸回数および分時換気量の関係一最大エント ロピー法による RRインターバルのスペクトル解 析一, 医学検査 , (1997), 46, 1356-1359. 
28) Cottin F., Papelier Y., Escourrou P. Effects of exercise load and breathing frequency on heart rate and blood pressure variability during dynamic exercise. Int. J. Sports Med., (1999), 20, 232-238.

29) 松本卓也, 松永篤彦, 石川 朗, 吉田弘法, 大須泰治, 齊藤正和, 米澤隆介, 石井 玲, 忽那俊樹, 山本壱弥, 小倉 彩, 増田 卓, 呼吸パターンの違いが有酸素 運動中の自律神経活動に及ぼす影響について, 体力 科学, (2005), 54, 482.

30) 中村好男, 山本義春, 健康の維持・増進のための適 正な運動強度の探索, 体力研究, (1991), 77, 82-91。
31) 䯽谷 満, 林由紀子, 関川清一, 川口浩太郎, 大成 浄志, 小林和典, 運動中の心拍変動と換気性作業閾 值との関連一MemCalc 法による検討一(第一報)，体 力科学，(2001), 50, 185-192.

32) Kasahara Y., Izawa K., Omiya K., Osada N., Watanabe W., Saitoh M., Matsunaga A., Masuda T. Influence of autonomic nervous dysfunction characterizing effects of diabetes mellitus on heart rate response and exercise capacity in patients undergoing cardiac rehabilitation for acute myocardial infarction. Circulation J., (2006), 70, 1017-1025. 